\title{
Evaluating the effectiveness of Australia's Small-scale Renewable Energy Scheme for rooftop solar
}

\section{CCEP Working Paper 1903 Aug 2019}

\section{Rohan Best}

Department of Economics, Macquarie University

\section{Paul J. Burke}

Crawford School of Public Policy, Australian National University

\section{Shuhei Nishitateno}

School of Policy Studies, Kwansei Gakuin University

\begin{abstract}
Australia has among the highest rates of small-scale solar photovoltaic adoption in the world, with substantial geographical variation in uptake. Using postcode-level data up to December 2018, we quantify the impact of Australia's spatially-differentiated Small-scale Renewable Energy Scheme on solar uptake. We use spatial autoregressive models and other approaches such as a regression discontinuity design. The results indicate that postcodes receiving a higher subsidy factor have significantly more small-scale solar installations, after controlling for solar exposure and spatial patterns in the data. The subsidy elasticity of small-scale solar capacity installations during 2018 was around 1.2. We use this estimate to calculate that an increase in the subsidy flowing to new installations would be able to reduce carbon dioxide emissions at a subsidy cost of around US $\$ 36$ per tonne, depending on assumptions.
\end{abstract}




\title{
Keywords:
}

solar energy; small-scale; subsidy; income distribution; spatial autoregressive model

\section{JEL Classification:}

H23, Q42, Q48, R11, R58

\section{Acknowledgements:}

We are grateful for feedback including from seminar participants at the Australian National University, Swinburne University, the National University of Singapore, the Indonesian Institute of Sciences (LIPI), the Australian-German Energy Transition Hub, and the Australian Agricultural and Resources Economics Society 2019 Conference. Funding was received from the Australian-German Energy Transition Hub and the Australian Research Council (DE160100750).

\section{Suggested Citation:}

Best, R., Burke, PJ. and Nishitateno, S. (2019), Evaluating the effectiveness of Australia's Small-scale Renewable Energy Scheme for rooftop solar, CCEP Working Paper 1903, Aug 2019. Crawford School of Public Policy, The Australian National University.

\author{
Address for Correspondence: \\ Rohan Best \\ Lecturer \\ Department of Economics \\ Macquarie University \\ Tel: +61 (2) 98507444 \\ Email: rohan.best@mq.edu.au
}

The Crawford School of Public Policy is the Australian National University's public policy school, serving and influencing Australia, Asia and the Pacific through advanced policy research, graduate and executive education, and policy impact.

The Centre for Climate Economics \& Policy is an organized research unit at the Crawford School of Public Policy, The Australian National University. The working paper series is intended to facilitate academic and policy discussion, and the views expressed in working papers are those of the authors. Contact for the Centre: Prof Frank Jotzo, frank.jotzo@anu.edu.au 


\section{Introduction}

Small-scale solar photovoltaic (PV) systems are having a transformational effect across Australia's electricity sector. As of December 2018, over 20\% of Australian households had rooftop solar PV systems, a rate that is among the highest in the world (Australian PV Institute, 2019; OECD, 2016). The total number of small-scale solar systems in Australia is similar to that in the United States (US), even though the US population is around 13 times larger (Australian PV Institute, 2019; SEIA, 2018).

There are several advantages of widespread adoption of rooftop solar. Rooftop solar can help to reduce carbon dioxide $\left(\mathrm{CO}_{2}\right)$ and other emissions from the electricity sector, while also reducing investment needs for utility-scale generation capacity to meet peak demand (AEMO, 2018; AER, 2017). Rooftop solar helps to reduce electricity bills for adopters and has the potential to place downward pressure on electricity prices. There is likely to be further growth in rooftop solar as the cost of solar panels continues to fall, as batteries and other enabling technologies improve, and in response to policy initiatives and high retail electricity prices (AEMO, 2018; AER, 2017).

This paper seeks to explain the considerable variation in small-scale solar uptake across Australian postcodes (see Figure 1). Our focus is on the role of the Small-scale Renewable Energy Scheme (SRES), which applies a subsidy that varies discretely across four postcode zones. We apply spatial autoregressive models to postcode-level data up to December 2018, controlling for many variables, to identify the subsidy elasticity of installations. The estimates indicate that the subsidy elasticity for the flow of small-scale solar capacity additions in 2018 was around 1.2. If the SRES subsidy factors were to be increased for new installations, we calculate that the scheme would reduce $\mathrm{CO}_{2}$ emissions at a subsidy cost of around US\$36 per tonne. 
Figure 1. Proportion of households with solar PV installations, December 2018, by postcode. Restricted to solar installations below 100 kilowatts $(\mathrm{kW})$.

$(0.32,0.74]$

$(0.23,0.32$

$(0.14,0.23$

$[0.00,0.14]$

$\square$ No data



Note: The proportion is calculated as the total number of solar PV installations divided by the number of households, although note that some of the installations are installed by businesses and others. Sources: ABS (2018), Clean Energy Regulator (2019). 
Our results on Australia's SRES are of practical relevance for policymakers who are considering supporting small-scale solar PV to address fuel poverty or to achieve emissions reduction goals. In addition, our paper is useful for predictive purposes to inform grid management planning. Our results and analysis may be useful for understanding how uptake may proceed in other countries.

\subsection{Small-scale Renewable Energy Scheme (SRES)}

A key component of Australian renewable energy policy has been a national renewable portfolio scheme, named the Renewable Energy Target (RET). The aim of the RET is to reduce greenhouse gas emissions through the creation of a market in renewable electricity certificates. The scheme started in 2001, with the aim of reaching 9,500 gigawatt hours of additional annual generation of renewable electricity by 2010 (Parliament of Australia, 2010). In 2009 the target was elevated to around 20\% of electricity coming from renewables by 2020. In 2011, the scheme was split into a Large-scale Renewable Energy Target (LRET) and a Small-scale Renewable Energy Scheme (SRES) (Australian Government, 2018). ${ }^{1}$ The SRES can make an uncapped contribution to the overall RET (Climate Change Authority, 2014).

The SRES has been the most important national policy instrument aimed at encouraging rooftop solar installations in Australia. There was an earlier Australian government rebate program, the Solar Homes and Communities Plan, but that closed in 2009 when the uptake rate was still only around $1 \%$. Other key policies, such as premium feed-in tariffs, have been implemented at the state level. Our specifications will include variables that control for the effects of such policies. ${ }^{2}$

A key design feature of the SRES is that postcodes with greater solar exposure receive a higher proportional subsidy, on account of their greater ability to generate electricity from rooftop panels. Postcodes are grouped into four zones according to their level of solar exposure (Australian Government, 2018), as shown in Figure 2. Postcode-level SRES subsidy factors take one of four discrete values:

\footnotetext{
Additional information on the Renewable Energy Target is available at http://www.cleanenergyregulator.gov.au/RET. Other types of small-scale energy generation, such as small-scale hydro, wind, and solar water heaters, are eligible under the SRES. However, solar PV accounts for the majority of installations, contributing $99.98 \%$ of electricity generation capacity under the SRES.

2 Specifically, we include electricity distribution network binary variables, as will be discussed later.
} 
- Zone 1: 1.622

- Zone 2: 1.536

- Zone 3: 1.382

- Zone 4: 1.185

The effective value of the upfront SRES subsidy is calculated as the product of: (a) the subsidy factor, (b) the size of the system in kilowatts, (c) the deeming period (initially 15 years, but reducing by one year per year from 2017 onwards), and (d) a variable certificate price with a maximum of 40 Australian dollars (A \$) per certificate. For example, a household installing a 3-kilowatt system in zone 3 in 2018 would have received a subsidy of approximately A $\$ 2,000$ - the product of a subsidy factor of 1.382 , 3 kilowatts of capacity, a 13-year deeming period and a certificate price of $\mathrm{A} \$ 35$, close to the maximum of $\mathrm{A} \$ 40$. This subsidy is substantial relative to the gross purchase price of approximately A $\$ 6,000$ (Solar Choice, 2018).

The SRES subsidy factors are based on a calculation by Australia's Clean Energy Regulator that approximates 1 certificate for $1 \mathrm{MWh}$ of future electricity generation. In contrast, the approach applied to large-scale projects under the Large-scale Renewable Energy Target (LRET) is that certificates are created per unit of renewable electricity that is actually generated.

The SRES subsidy is paid by electricity retailers and other purchasers of wholesale electricity, who are obligated to buy the small-scale technology certificates. The cost is then largely passed on to electricity consumers. In practice, the scheme works as an upfront capital subsidy that reduces the purchase price (i.e. an investment subsidy), with households paying a price for their installations that is net of the SRES subsidy. Some may not be aware of the magnitude of the subsidy.

Interestingly, a comparison of Figures 1 and 2 suggests that the solar PV uptake rate is not always higher in areas receiving the highest subsidy factors. For example, zone 1's uptake is substantially lower than zone 2's, despite zone 1 receiving a higher subsidy factor. However, to properly identify the effect of the subsidy factor it is necessary to consider the effects of other factors that may be important for solar uptake. If there are other relevant factors that happen to be spatially correlated with the subsidy factors, the conditional effect of the subsidy factor would differ from the unconditional associations. 
Figure 2. Postcode allocation into four zones that receive different subsidy factors.

Zone 4

Zone 3

Zone 2

Zone 1



Note: The zone 1 subsidy factor is 1.622 , zone 2 is 1.536 , zone 3 is 1.382 , and zone 4 is 1.185 . Source: Australian Government (2018). 


\subsection{Contributions}

There have been several US studies on small-scale solar policy effectiveness using region-level data. Subsidies have been found to be effective in contributing to solar uptake and displacing $\mathrm{CO}_{2}$ emissions from alternative electricity generation sources in some US regions, with the cost-effectiveness of these emissions reductions appearing to have been superior in California than in the north-east of the US (Crago and Chernyakhovskiy, 2017; Gillingham and Tsvetanov, 2019; Hughes and Podolefsky, 2015). These papers have focused on quite early phases of rooftop solar adoption. The rooftop solar market has achieved a higher level of maturity in Australia.

There are also some studies of policy impacts for early uptake of small-scale solar in Australia. Chapman et al. (2016) concluded that feed-in tariffs were a dominant contributor to rooftop solar PV deployment over the period to 2012. Capital subsidies from the SRES were found to have provided sizable aggregate private benefits for recipient households up to 2014 (Mountain and Szuster, 2015). Macintosh and Wilkinson (2011) analysed the effects of the Solar Homes and Communities Plan, the earlier Australian rebate program for residential solar PV that was terminated in 2009. They concluded that the average cost of reduced emissions, including the solar panel cost, was approximately $\mathrm{A} \$ 250$ per tonne of $\mathrm{CO}_{2}$ equivalent.

We also seek to add to prior literature that examines the effectiveness of energy policies applied at various regions and scales. For example, Bruegge et al. (2016) found that a program targeting energy efficient homes in Florida had mixed success. Home energy efficiency labelling in California has been assessed more favourably (Kahn and Kok, 2014). Best and Burke (2018) pursued cross-country analysis, finding that carbon pricing is associated with faster uptake of solar power. Many studies do not empirically assess policy cost-effectiveness.

There are many driving forces for solar technology uptake other than policy. Prior studies have found a positive impact of income on uptake of household solar PV (De Groote et al., 2016; Kwan, 2012) and solar water heaters (Aydin et al., 2018). Using a survey approach, Bondio et al. (2018) concluded that solar PV uptake in Queensland is most popular among the middle class. Solar exposure is a key geographical explanator, with Kwan (2012) finding a positive impact on uptake in the United States. Clustering 
of high solar panel penetration in some regions may also partly reflect peer learning (Bollinger and Gillingham, 2012). Lower uptake by renters may be due to property rights constraints (Ameli and Brandt, 2015; Karakaya and Sriwannawit, 2015). Apartment dwellers may also face space constraints and transaction costs that impede uptake (Best et al., in press; Roberts et al., 2019). Older people have been found to be more likely to adopt solar panels in the Australian state of Queensland (Sommerfeld et al., 2017). Environmental preferences are likely to matter (Briguglio \& Formosa, 2017; Dharshing, 2017).

Our paper's main contribution is its analysis of the impact of the SRES on small-scale solar uptake in Australia. Our identification strategy uses sharp geographical discontinuities in the SRES subsidy factor, while controlling for other determinants of uptake including underlying solar conditions in each postcode and spatial autocorrelations. Our cross-postcode approach is well-suited to our focus on the SRES subsidy factor (which varies geographically), and Australia is an important case study given that it is a world leader in rooftop solar. The SRES is the main national policy instrument used to encourage rooftop solar installations to date. Further, our analysis includes variables that have received little attention in the prior literature, such as the proportion of households with a mortgage. We also consider the effects of income distribution at the postcode level.

\section{Method and data}

\subsection{Econometric models and variables}

We use a reduced-form cross-sectional analysis to explain spatial variation in rooftop solar uptake, with a focus on exploiting the sharp geographical discontinuities in subsidy zones to evaluate the impact of the SRES. These subsidy zones have been timeinvariant since introduction in 2011, supporting the use of cross-sectional rather than time-series analysis. We focus on solar uptake rates across regions rather than other issues such as the distribution of welfare gains between households and installation companies. We also consider temporal aspects by assessing annual flows of installation capacity. Our initial model is:

$$
S_{p}^{j}=\theta^{j} \ln Z_{p}+\boldsymbol{P}_{p}^{\prime} \boldsymbol{\alpha}^{j}+\boldsymbol{E}_{p}^{\prime} \boldsymbol{\beta}^{j}+\boldsymbol{G}_{p}^{\prime} \boldsymbol{\gamma}^{j}+\boldsymbol{H}^{\prime}{ }_{p} \boldsymbol{\delta}^{j}+\varepsilon_{p}^{j}
$$


$S_{p}^{j}$ is a dependent variable representing small-scale solar uptake in each postcode $(p)$. The $j$ superscript represents alternative solar PV installation variables. We use the number of solar installations divided by the number of households. We also use the log of small-scale solar installation capacity in kilowatts. In addition, we present results for annual flows of solar capacity. Estimates in logs allow direct estimation of key elasticities.

$Z$ is the SRES subsidy rating factor. In an alternative specification, we instead include binary variables for SRES zones to assess treatment effects on a zone-by-zone basis. These two approaches can contribute to a robust understanding of the effect of the SRES subsidy factor on rooftop solar adoption.

Other policy support is contained in the $\boldsymbol{P}$ vector. This is proxied by binary variables for the 16 electricity distribution areas in Australia. ${ }^{3}$ These control for feed-in tariff differences that have varied across electricity distribution networks, in part due to state policies. ${ }^{4}$ The distribution network variables also account for electricity price differences across regions.

The $\boldsymbol{E}$ vector contains economic variables, including log median income, the proportion of households with a mortgage, the log number of employing businesses divided by population, and log superannuation balances as a proxy for accumulated capital. ${ }^{5} \mathrm{We}$ also include the proportions of households that fall in discrete income ranges. Figure 3 suggests that postcodes with higher shares of middle-income households are more likely to have high solar penetration rates. We form four income bands - based on similarities in the correlations in Figure 3 - to test this middle-income hypothesis econometrically.

Each of the eight Australian states and territories have between one and five electricity distribution areas. A small number of postcodes fall in two distribution areas.

The most generous of the state-based feed-in tariff schemes were closed to new customers during 2011-2013.

Superannuation is the word used for retirement savings accounts in Australia. Superannuation is a large component of household wealth and is not subject to sizeable endogeneity concerns. Other assets such as home values might be more subject to reverse causation (Ma et al., 2015). We use median superannuation values, which are available at the postcode level. 
Figure 3. Correlations using Australian postcode-level data between (i) solar PV installations per household in December 2018 and (ii) the proportion of households in each household income sub-band.

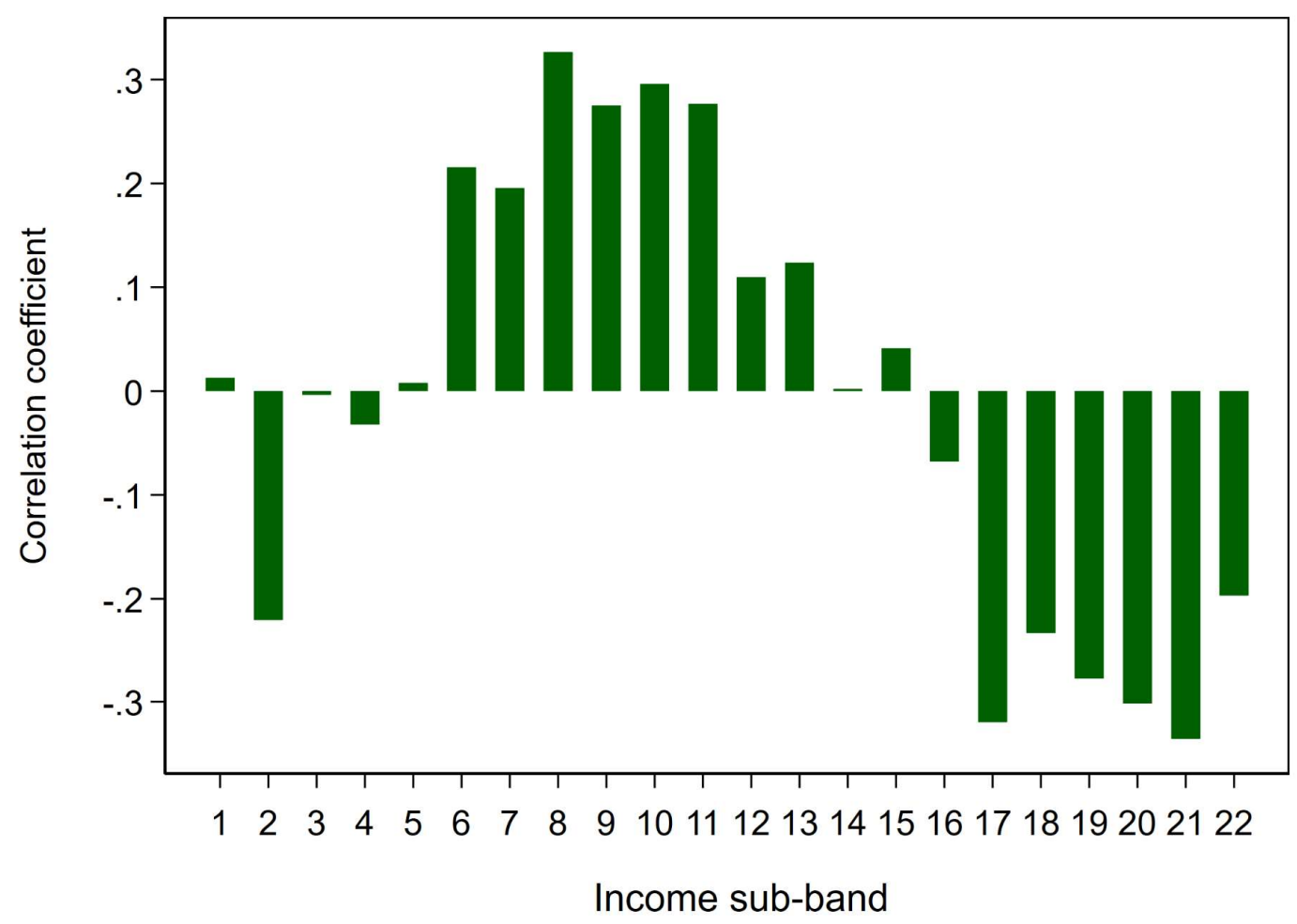

Notes: 22 household income-sub bands are used, as defined in Table A.1. They are ordered from the lowest to the highest household incomes. For example, income sub-band 11 is A $\$ 65,000-77,999$. We go on to categorize income sub-bands $1-5$ as low-income, income subbands $6-11$ as lower-middle income, income sub-bands $12-16$ as upper-middle income, and income sub-bands 17-22 as high income. Source: based on 2016 census data (ABS, 2018).

The pre-subsidy price of installed solar systems is a factor that also likely affects uptake. We do not include this in the $\boldsymbol{E}$ vector for several reasons. One is that presubsidy installation prices tend to be quite similar in many key locations across the country. For instance, the gross price for installing a 5 kilowatt system was approximately A $\$ 10,000$ in each of the three largest urban areas of Sydney, Melbourne, and Brisbane as of June 2016 (Solar Choice, 2018), and was similar in regional areas (Solar Choice, 2018; Sunny Solar, 2018). Prices in very remote areas tend to be higher (Country Solar NT, 2018), which we partly control for via a set of regional binary variables (and also our distribution network binary variables). Regional binary variables are included for major cities, inner-regional areas, outer-regional areas, remote areas, and very remote areas. This approach also allows us to explain solar uptake with more 
convincingly exogenous variables, avoiding identification issues related to potentially endogenous prices. Figure 4 shows that proportional uptake has been highest in innerregional areas and lowest in very remote areas.

Figure 4. Proportions of households with solar PV installations, December 2018, by remoteness area.

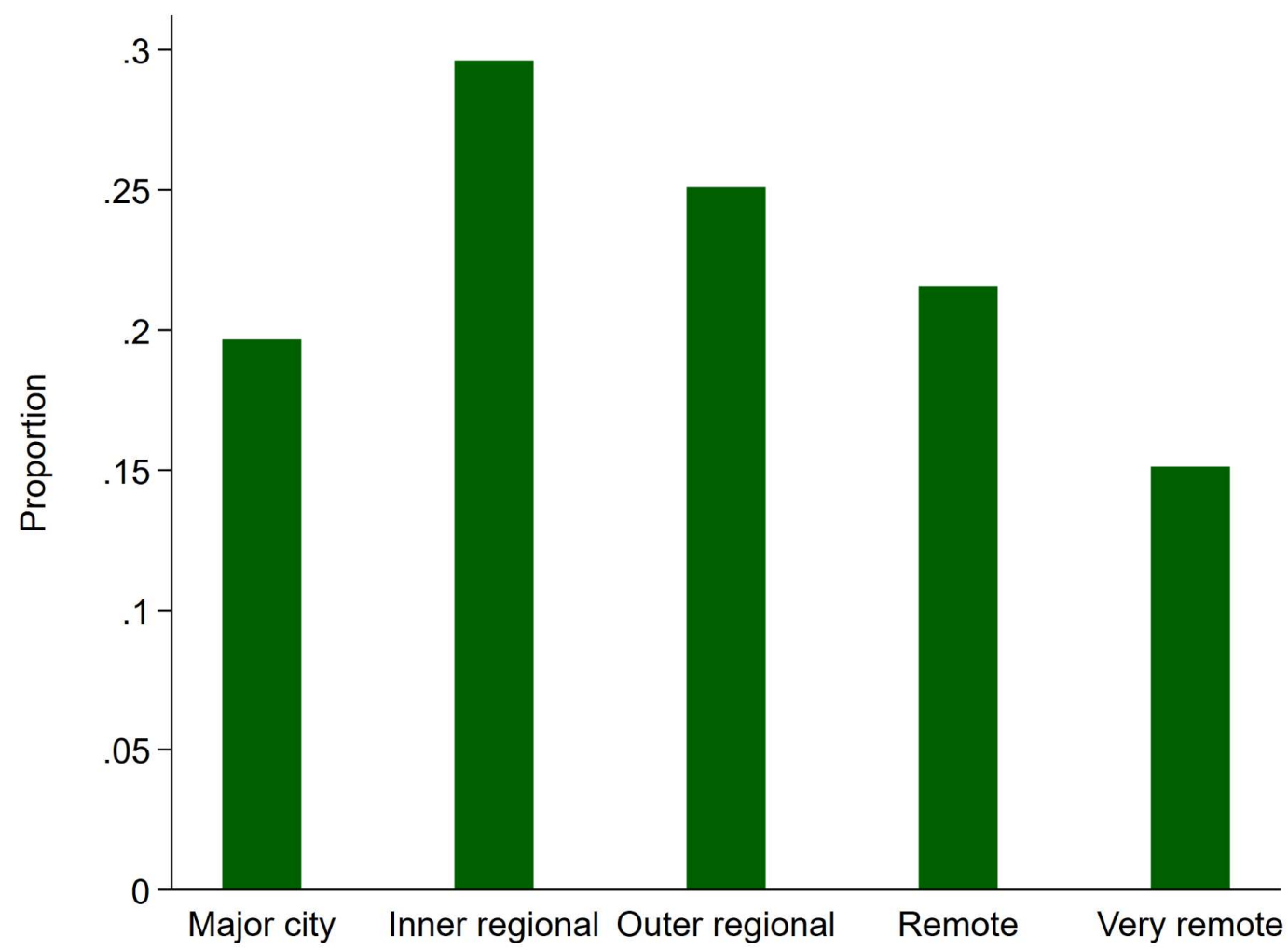

Note: Restricted to solar installations below 100kW. Sources: ABS (2018); Clean Energy Regulator (2019).

The $\boldsymbol{G}$ and $\boldsymbol{H}$ vectors include a range of other geographic and household characteristics. A key variable is log solar exposure in megajoules per metre squared. Conditioning on this, the log SRES subsidy factor should provide the marginal effect of a higher subsidy factor when crossing from one side of a subsidy-zone border to another. We also include an enhanced vegetation index to measure potential tree shading of roofs, as well as the $\log$ land area for each postcode and the log number of households. In addition, in robustness tests we include binary variables for each of 69 climate zones. Household characteristics include occupant age, the shares of households that rent and that live in flats/apartments, the proportion of residences with one bedroom or less, and the share of voters that voted for an environmental political party in the 2016 federal election. In 
addition, we use a variable representing the proportion of households for which all residents lived at a different address a year prior. This partly accounts for house age, which is not available at the postcode level, as people in newer houses are more likely to have recently moved in.

A Moran (1950) test for spatial dependence rejects the null hypothesis that errors in an ordinary least squares regression of equation 1 are independent and identically distributed. This suggests that residuals are correlated across postcodes. As a result, we add a $\boldsymbol{W S}$ term in equation 2, with $\boldsymbol{W}$ being a weighting matrix that specifies spatial correlations in the dependent variable $(S)$ across postcodes, based on the assumption that only adjacent postcodes affect each other, and using scaling weights that have a maximum eigenvalue of one. We use equation 2 for our econometric estimations:

$S_{p}^{j}=\theta^{j} \ln Z_{p}+\boldsymbol{P}_{p}^{\prime} \boldsymbol{\alpha}^{j}+\boldsymbol{E}_{p}^{\prime} \boldsymbol{\beta}^{j}+\boldsymbol{G}^{\prime}{ }_{p} \boldsymbol{\gamma}^{j}+\boldsymbol{H}^{\prime}{ }_{p} \boldsymbol{\delta}^{j}+\boldsymbol{W} \boldsymbol{S}_{p}^{\prime} \boldsymbol{\mu}^{j}+\varepsilon_{p}^{j}$

We then employ a regression discontinuity approach that relies on comparing postcodes contiguous to a subsidy-zone border (and excluding other postcodes). The bordering postcodes are more likely to be similar along many dimensions, leaving zone allocation as the key potential determinant of variation in solar uptake. The regression discontinuity specifications include our controls, most importantly log solar exposure. The downsides of this approach include reduced sample sizes and potentially lower external validity, as effects for border postcodes may not be fully representative of effects across the broader sample.

Further, we produce propensity score matching results for the subsidy-zone border postcodes. This involves matching postcodes from one subsidy zone with postcodes in a neighbouring subsidy zone, based on similarity of covariates. We include only latitude and longitude as covariates in the propensity score (conditional probability of treatment) model, since the allocation of postcodes into the four subsidy zones is based on solar exposure, which is a function of geography. We can then calculate the average treatment effect by taking the difference between solar uptake in each postcode and its matched postcode. 


\subsection{Potential endogeneity issues}

There is an identification challenge in measuring the impact of the SRES subsidy, as the subsidy zones are not randomly assigned to each postcode. If the SRES subsidy factors were randomly assigned, they would be independent of all other determinants of solar uptake, and subsequent differences in solar uptake could be causally related to the policy. This type of experiment has not been implemented.

Our approach uses multiple strategies to achieve accurate identification of the effect of the SRES subsidy. First, we include a large suite of control variables, including a continuous measure of solar exposure. Our estimations are able to explain high proportions of the variation in small-scale solar uptake across Australia. Second, our spatial autoregressive model controls for hard-to-observe spatial effects, including possible peer effects. Third, we include regional variables to account for unobserved heterogeneity across regions. This includes 16 binary variables for electricity distribution network areas (main paper) and 69 binary variables for climate zones (online Stata code). This is similar to the approach of De Groote et al. (2016) of including binary regional fixed effects for each municipality in Flanders, Belgium. Fourth, we produce regression discontinuity and propensity score matching results for sub-samples of postcodes that are contiguous with zone borders. It is less likely that there is heterogeneity across other dimensions for these border postcodes. As mentioned, our regression discontinuity approach controls for the effects of observed differences in solar exposure and other variables.

\subsection{Data}

We use solar PV data for installations in the $0-100$ kilowatt range, as this is the size range that applies for the SRES. As of December 2018, over $80 \%$ of the capacity in the 0-100 kilowatt range was rooftop installations of less than or equal to 9.5 kilowatts (Australian PV Institute, 2019). The online Stata code includes robustness tests using data for the $0-10$ kilowatt range, showing similar results.

Many of our control variables are sourced from the ABS (2018). This includes the number of households and the number of employing businesses in local labour markets, as recorded in the 2016 Australian census. The median taxable income and superannuation balance for each postcode are from the Australian Tax Office (2018). 
The enhanced vegetation index is available at the postcode level for 2012 (Raschky and Rosetti, 2014). Solar exposure data are from the Bureau of Meteorology (2018). Climate zones are from the Department of Industry, Innovation and Science (2015). Electricity distributor binary variables are based on distributor websites and email correspondence. Environmental preferences are represented by environmental party vote percentages in the 2016 federal election (Australian Electoral Commission, 2016). Detailed data definitions are in Appendix Table A.1.

Postcode-level installation data for small-scale solar PV systems are available for almost the whole country (approximately 2,800 of Australia's 3,000 postcodes). Our regressions drop postcodes with less than 100 households. Results are robust to different sample selection criteria, such as excluding postcodes with less than 1,000 households, or not excluding any postcodes based on household numbers.

Table 1 includes descriptive statistics for each of the four zones. As also suggested by Figures 1 and 2, solar uptake is lowest in zone 1, even though this zone receives the highest subsidy factor. This may relate to zone 1 covering very remote areas. Zone 2 postcodes are evenly split between outer regional, remote, and very remote locations. Some of the factors that constrain solar uptake in zone 1 would also be relevant for zone 2 to a lesser extent. Zones 3 and 4 are mostly major cities and surrounding regions, but also include considerable numbers of outer-regional postcodes. 
Table 1. Descriptive statistics using Australian postcode data, mean $(\mu)$ and standard deviation $(\sigma)$ for each zone.

\begin{tabular}{|c|c|c|c|c|c|c|c|c|}
\hline Variable & Zone $1 \mu$ & Zone $2 \mu$ & Zone $3 \mu$ & Zone $4 \mu$ & Zone $1 \sigma$ & Zone $2 \sigma$ & Zone $3 \sigma$ & Zone $4 \sigma$ \\
\hline Proportion of households with solar installations * & 0.07 & 0.24 & 0.26 & 0.19 & 0.08 & 0.12 & 0.13 & 0.11 \\
\hline Kilowatts of PV installed $(0-100 \mathrm{~kW})$ up to $31 \mathrm{Dec} 2018$ & $1,051.30$ & $1,872.32$ & $4,333.84$ & $2,424.28$ & $2,317.89$ & $3,086.59$ & $5,590.53$ & $3,243.14$ \\
\hline Kilowatts of PV installed (0-100kW) during 2015 & 106.78 & 192.33 & 363.25 & 229.96 & 313.02 & 299.88 & 473.17 & 326.03 \\
\hline Kilowatts of PV installed (0-100kW) during 2016 & 117.95 & 220.73 & 387.71 & 220.76 & 353.11 & 367.66 & 527.80 & 297.72 \\
\hline Kilowatts of PV installed ( $0-100 \mathrm{~kW})$ during 2017 & 118.54 & 277.72 & 601.40 & 313.12 & 317.07 & 514.08 & 821.17 & 414.95 \\
\hline Kilowatts of PV installed $(0-100 \mathrm{~kW})$ during 2018 & 160.18 & 375.82 & 813.88 & 483.83 & 385.81 & 708.67 & $1,061.92$ & 767.01 \\
\hline Major city, binary & 0.00 & 0.00 & 0.47 & 0.36 & 0.00 & 0.00 & 0.50 & 0.48 \\
\hline Inner regional, binary & 0.00 & 0.01 & 0.24 & 0.36 & 0.00 & 0.09 & 0.43 & 0.48 \\
\hline Outer regional, binary & 0.00 & 0.37 & 0.24 & 0.25 & 0.00 & 0.48 & 0.43 & 0.43 \\
\hline Remote, binary & 0.22 & 0.29 & 0.04 & 0.02 & 0.42 & 0.46 & 0.19 & 0.15 \\
\hline Very remote, binary & 0.78 & 0.33 & 0.01 & 0.01 & 0.42 & 0.47 & 0.09 & 0.08 \\
\hline Number of households & $2,132.48$ & $1,729.29$ & $4,816.68$ & $4,136.68$ & $2,467.01$ & $2,885.85$ & $5,451.48$ & $5,080.03$ \\
\hline Area, square kilometres & $89,391.55$ & $14,235.78$ & $1,104.37$ & 469.62 & $199,497.40$ & $25,868.59$ & $5,136.51$ & $1,181.10$ \\
\hline Enhanced vegetation index & 0.13 & 0.21 & 0.30 & 0.33 & 0.02 & 0.05 & 0.07 & 0.08 \\
\hline Solar exposure, megajoules per metre squared & 21.84 & 20.27 & 17.74 & 14.97 & 0.97 & 1.12 & 1.22 & 0.88 \\
\hline Rented households * & 0.34 & 0.20 & 0.21 & 0.17 & 0.13 & 0.10 & 0.10 & 0.10 \\
\hline Units (flats/apartments) * & 0.06 & 0.05 & 0.10 & 0.06 & 0.07 & 0.10 & 0.17 & 0.14 \\
\hline One bedroom or less * & 0.13 & 0.08 & 0.05 & 0.04 & 0.07 & 0.07 & 0.05 & 0.04 \\
\hline One-year mobility indicator * & 0.10 & 0.08 & 0.09 & 0.08 & 0.04 & 0.04 & 0.04 & 0.04 \\
\hline Environmental vote $*$ & 0.09 & 0.05 & 0.08 & 0.12 & 0.04 & 0.04 & 0.06 & 0.09 \\
\hline Persons aged $40-60$ years * & 0.32 & 0.28 & 0.27 & 0.28 & 0.05 & 0.04 & 0.03 & 0.04 \\
\hline Persons aged over 60 years * & 0.16 & 0.26 & 0.25 & 0.25 & 0.09 & 0.09 & 0.08 & 0.08 \\
\hline Mortgage * & 0.07 & 0.15 & 0.27 & 0.28 & 0.07 & 0.09 & 0.10 & 0.11 \\
\hline \# employing businesses in SA4 divided by postcode population & 2.82 & 5.81 & 3.74 & 5.25 & 3.41 & 6.34 & 5.66 & 7.17 \\
\hline Median superannuation balance (A\$) & $35,573.39$ & $36,804.75$ & $44,476.32$ & $47,501.93$ & $21,967.76$ & $11,405.18$ & $15,558.65$ & $19,510.22$ \\
\hline Median individual income (A\$) & $61,007.57$ & $42,783.12$ & $42,560.59$ & $40,263.49$ & $24,890.98$ & $9,359.66$ & $8,398.75$ & $6,530.58$ \\
\hline Household income (annual) up to A $\$ 20,799 *$ & 0.05 & 0.06 & 0.06 & 0.06 & 0.03 & 0.03 & 0.02 & 0.03 \\
\hline Household income (annual) A \$20,800-A \$77,999* & 0.23 & 0.31 & 0.35 & 0.35 & 0.10 & 0.09 & 0.08 & 0.08 \\
\hline Household income (annual) A $\$ 78,000-A \$ 181,999 *$ & 0.23 & 0.20 & 0.25 & 0.24 & 0.06 & 0.07 & 0.08 & 0.08 \\
\hline Household income (annual) above A $\$ 181,999 *$ & 0.10 & 0.05 & 0.08 & 0.06 & 0.08 & 0.04 & 0.07 & 0.06 \\
\hline
\end{tabular}

Notes: The statistics are for 2,213 postcodes with data for each variable and at least 100 total dwellings. There are 23 postcodes in zone 1,119 in zone $2,1,410$ in zone 3 , and 661 in zone 4. Proportional variables are identified with a star $\left(^{*}\right)$ and use the total number of households in each postcode as the denominator, including households that did not state responses for some variables. We control for the proportion of households that do not report income in Tables $2-4$ and exclude the proportion above A\$181,999 as the reference income group. SA4 is statistical area level 4. Solar PV data are up to December 2018 and do not include hot water systems. 


\section{Results}

\subsection{Estimates for the current stock of rooftop solar}

Estimation results for the total stock of small-scale solar systems as at 31 December 2018 are shown in Table 2. Column 1 shows a positive effect of the log of the SRES subsidy factor on log small-scale solar PV capacity, with significance at the $1 \%$ level. We also find positive and significant coefficients in explaining proportional uptake in columns 2 and 3, significant at the 1\% level. Looking across postcodes, a $1 \%$ higher SRES subsidy factor is associated with 0.2 percentage points in additional solar PV uptake, holding the other variables constant. ${ }^{6}$

Column 4 of Table 2 analyses the subsidy-zone treatment effects for three zones relative to the excluded zone 4 , where the lowest subsidy factor applies. The coefficient for zone 1 is positive and significant at the 5\% level, while the coefficients for zones 2 and 3 are positive and significant at the $1 \%$ level. Uptake in zone 3 is three percentage points higher than in the excluded zone 4, all else equal. This is maintained if the sample is restricted to only zone 3 and zone 4 households (see online robustness tests). Solar uptake is seven percentage points higher in zone 2 compared to zone 4 , all else equal. The coefficient for zone 2 is higher than that for zone 3 , as expected given the higher subsidy factor in zone $2 .^{7}$ That the effect for zone 1 is estimated with somewhat less precision may be because only $1 \%$ of postcodes are in zone 1 . Given that we have controlled for solar exposure and many other variables, the estimates likely reflect the impact of the different SRES subsidy factors across the zones.

The subsidy coefficients in columns 3 and 4 of Table 2 relate closely to one another. For instance, a 30\% increase in the SRES subsidy factor is associated with an increase in solar PV penetration of seven percentage points, based on multiplying the column 3 coefficient of 0.24 by 30 . When considering that the zone- 2 subsidy factor is $30 \%$ higher than the zone-4 subsidy factor, this gives a similar result to the seven percentage points in column 4.

Spatial autoregressive coefficients can be split into direct and indirect effects, but the total effects are almost identical to the direct effects in our case.

The zone 2 and zone 3 coefficients are statistically different at the $1 \%$ level (see the online code). 
Table 2 also shows that inner-regional areas have higher penetrations of solar panels relative to the excluded category of major cities, all else equal. This is consistent with the unconditional effect in Figure 4. Solar uptake is approximately five percentage points higher in inner-regional areas compared to major cities (column 2, when controlling for other variables). This magnitude is less than the unconditional effect in Figure 4. There is a negative effect of remote areas on log solar capacity, but a positive effect on the proportion of households with solar installations. This could be because households in remote areas have installed some rather small systems.

Other geographic influences are also evident in Table 2. There is a positive association between the vegetation index variable and uptake, suggesting that shading by trees is not a widespread constraint. Perhaps the vegetation index is partly picking up environmental preferences. Greater solar exposure is associated with more small-scale solar uptake, as expected. ${ }^{8}$

8 In the online code, we also included a squared log solar exposure term to control for potential non-linear effects of log solar exposure. It could be possible, for instance, that additional solar exposure may not induce additional solar PV uptake once a certain level of solar exposure is reached, perhaps due to solar-cell inefficiency at high temperatures. However, we do not find significant non-linear effects for this variable. 
Table 2. Results for solar installations as at 31 December 2018.

\begin{tabular}{|c|c|c|c|c|}
\hline \multirow[b]{2}{*}{ Explanatory variables: } & \multirow{2}{*}{$\begin{array}{l}\text { Log solar PV } \\
\text { capacity } \\
\text { (1) }\end{array}$} & \multicolumn{3}{|c|}{$\begin{array}{l}\text { Number of households with solar PV } \\
\text { installations divided by number of households }\end{array}$} \\
\hline & & (2) & (3) & (4) \\
\hline SRES subsidy factor, log & $\begin{array}{l}0.631 * * * \\
(0.230)\end{array}$ & $\begin{array}{l}0.222 * * * \\
(0.044)\end{array}$ & $\begin{array}{l}0.235 * * * \\
(0.044)\end{array}$ & \\
\hline SRES subsidy zone 1 (factor $=1.622)$, binary & & & & $\begin{array}{l}0.046 * * \\
(0.021)\end{array}$ \\
\hline SRES subsidy zone 2 (factor $=1.536)$, binary & & & & $\begin{array}{l}0.071 * * * \\
(0.012)\end{array}$ \\
\hline SRES subsidy zone 3 (factor $=1.382$ ), binary & & & & $\begin{array}{l}0.032 * * * \\
(0.008)\end{array}$ \\
\hline Inner regional & $\begin{array}{l}0.057^{*} \\
(0.032)\end{array}$ & $\begin{array}{l}0.053 * * * \\
(0.006)\end{array}$ & $\begin{array}{l}0.051 * * * \\
(0.006)\end{array}$ & $\begin{array}{l}0.051 * * * \\
(0.006)\end{array}$ \\
\hline Outer regional & $\begin{array}{l}-0.029 \\
(0.041)\end{array}$ & $\begin{array}{l}0.031 * * * \\
(0.008)\end{array}$ & $\begin{array}{l}0.029 * * * \\
(0.008)\end{array}$ & $\begin{array}{l}0.029 * * * \\
(0.008)\end{array}$ \\
\hline Remote & $\begin{array}{l}-0.171 * * * \\
(0.059)\end{array}$ & $\begin{array}{l}0.036^{* * *} \\
(0.011)\end{array}$ & $\begin{array}{l}0.035 * * * \\
(0.011)\end{array}$ & $\begin{array}{l}0.031 * * * \\
(0.011)\end{array}$ \\
\hline Very remote & $\begin{array}{l}-0.234 * * * \\
(0.081)\end{array}$ & $\begin{array}{l}0.001 \\
(0.015)\end{array}$ & $\begin{array}{l}-0.002 \\
(0.015)\end{array}$ & $\begin{array}{l}-0.006 \\
(0.015)\end{array}$ \\
\hline Area, square kilometres, log & $\begin{array}{l}0.060 * * * \\
(0.007)\end{array}$ & $\begin{array}{l}0.003 * \\
(0.001)\end{array}$ & $\begin{array}{l}0.002 \\
(0.001)\end{array}$ & $\begin{array}{l}0.002 \\
(0.001)\end{array}$ \\
\hline Enhanced vegetation index & $\begin{array}{l}0.538 * * * \\
(0.137)\end{array}$ & $\begin{array}{l}0.105 * * * \\
(0.026)\end{array}$ & $\begin{array}{l}0.106 * * * \\
(0.026)\end{array}$ & $\begin{array}{l}0.109 * * * \\
(0.026)\end{array}$ \\
\hline Solar exposure, log & $\begin{array}{l}2.316^{* * * *} \\
(0.220)\end{array}$ & $\begin{array}{l}0.332 * * * \\
(0.042)\end{array}$ & $\begin{array}{l}0.326 * * * \\
(0.042)\end{array}$ & $\begin{array}{l}0.327 * * * \\
(0.042)\end{array}$ \\
\hline Rented households, \%/100 & $\begin{array}{l}-0.649 * * * \\
(0.183)\end{array}$ & $\begin{array}{l}-0.097 * * * \\
(0.035)\end{array}$ & $\begin{array}{l}-0.178 * * * \\
(0.041)\end{array}$ & $\begin{array}{l}-0.170 * * * \\
(0.041)\end{array}$ \\
\hline Units (flats/apartments), $\% / 100$ & $\begin{array}{l}-1.161 * * * \\
(0.095)\end{array}$ & $\begin{array}{l}-0.070 * * * \\
(0.018)\end{array}$ & $\begin{array}{l}-0.048 * * \\
(0.019)\end{array}$ & $\begin{array}{l}-0.048^{* *} \\
(0.019)\end{array}$ \\
\hline One bedroom or less, $\% / 100$ & $\begin{array}{l}-1.118 * * * \\
(0.265)\end{array}$ & $\begin{array}{l}-0.139 * * * \\
(0.051)\end{array}$ & $\begin{array}{l}-0.145 * * * \\
(0.052)\end{array}$ & $\begin{array}{l}-0.152 * * * \\
(0.052)\end{array}$ \\
\hline One-year mobility indicator, $\% / 100$ & $\begin{array}{l}2.672 * * * \\
(0.382)\end{array}$ & $\begin{array}{l}0.166^{* *} \\
(0.074)\end{array}$ & $\begin{array}{l}0.167 * * \\
(0.073)\end{array}$ & $\begin{array}{l}0.162 * * \\
(0.073)\end{array}$ \\
\hline Environmental vote, $\% / 100$ & $\begin{array}{l}0.144 \\
(0.163)\end{array}$ & $\begin{array}{l}0.023 \\
(0.031)\end{array}$ & $\begin{array}{l}0.049 \\
(0.032)\end{array}$ & $\begin{array}{l}0.047 \\
(0.032)\end{array}$ \\
\hline Proportion aged $40-60$ years & $\begin{array}{l}-0.746^{* *} \\
(0.313)\end{array}$ & $\begin{array}{l}-0.008 \\
(0.060)\end{array}$ & $\begin{array}{l}-0.006 \\
(0.061)\end{array}$ & $\begin{array}{l}0.003 \\
(0.061)\end{array}$ \\
\hline Proportion aged over 60 years & $\begin{array}{l}0.791 * * * \\
(0.193)\end{array}$ & $\begin{array}{l}0.233 * * * \\
(0.037)\end{array}$ & $\begin{array}{l}0.180 * * * \\
(0.043)\end{array}$ & $\begin{array}{l}0.182 * * * \\
(0.043)\end{array}$ \\
\hline Mortgage, $\% / 100$ & $\begin{array}{l}2.093 * * * \\
(0.143)\end{array}$ & $\begin{array}{l}0.550 * * * \\
(0.028)\end{array}$ & $\begin{array}{l}0.470 * * * \\
(0.038)\end{array}$ & $\begin{array}{l}0.471 * * * \\
(0.038)\end{array}$ \\
\hline $\begin{array}{l}\text { Number of employing businesses divided } \\
\text { by population, log }\end{array}$ & $\begin{array}{l}-0.065 * * * \\
(0.021)\end{array}$ & $\begin{array}{l}0.010 * * * \\
(0.002)\end{array}$ & $\begin{array}{l}0.009 * * * \\
(0.002)\end{array}$ & $\begin{array}{l}0.009 * * * \\
(0.002)\end{array}$ \\
\hline Median superannuation balance, $\log$ & $\begin{array}{l}0.087 * * \\
(0.036)\end{array}$ & $\begin{array}{l}-0.008 \\
(0.007)\end{array}$ & $\begin{array}{l}-0.005 \\
(0.007)\end{array}$ & $\begin{array}{l}-0.006 \\
(0.007)\end{array}$ \\
\hline Median income, log & $\begin{array}{l}-0.636 * * * \\
(0.087)\end{array}$ & $\begin{array}{l}-0.082 * * * \\
(0.017)\end{array}$ & $\begin{array}{l}-0.057 * * * \\
(0.019)\end{array}$ & $\begin{array}{l}-0.056 * * * \\
(0.018)\end{array}$ \\
\hline $\begin{array}{l}\text { Household income up to } \mathrm{A} \$ 20,799 \\
(\% / 100)\end{array}$ & & & $\begin{array}{l}0.020 \\
(0.095)\end{array}$ & $\begin{array}{l}0.016 \\
(0.094)\end{array}$ \\
\hline $\begin{array}{l}\text { Household income A } \$ 20,800-\mathrm{A} \$ 77,999 \\
(\% / 100) \\
\text { Household income A } \$ 78,000-\mathrm{A} \$ 181,999 \\
(\% / 100)\end{array}$ & & & $\begin{array}{l}0.172 * * * \\
(0.047) \\
0.119 * * \\
(0.061)\end{array}$ & $\begin{array}{l}0.167^{* * *} \\
(0.047) \\
0.110 * \\
(0.061)\end{array}$ \\
\hline Spatial auto-regressive term & $\begin{array}{l}0.015^{* * * *} \\
(0.004)\end{array}$ & $\begin{array}{l}0.095 * * * \\
(0.020)\end{array}$ & $\begin{array}{l}0.093 * * * \\
(0.020)\end{array}$ & $\begin{array}{l}0.096^{* * *} \\
(0.020)\end{array}$ \\
\hline Total dwellings, log & $\begin{array}{l}0.845^{* * * *} \\
(0.022)\end{array}$ & & & \\
\hline Regional binary variables & Yes & Yes & Yes & Yes \\
\hline$R^{2}$ & 0.94 & 0.73 & 0.73 & 0.73 \\
\hline
\end{tabular}

Notes. ***, **, * show statistical significance at 1, 5 and 10 per cent level respectively. Standard errors are in brackets below the coefficients. Coefficients for constants are not shown. Regional binary variables are for electricity distributor areas. The online Stata code shows robustness tests using climate-zone binary variables, producing similar results. There are 2,213 observations in each column. We also include a variable to control for the proportion of households that do not report income in column 3 and 4, but the coefficient is insignificant. A hypothesis test that the log total dwellings coefficient is 1 is not rejected at the $5 \%$ level if the dependent variable is the log solar installation count. 
Table 2 also provides evidence of effects of household characteristics. There are negative and significant coefficients for the renting, apartment, and one bedroom or less variables, indicative of property rights and space constraints. Postcodes with more households who have moved in the last year have higher proportional solar uptake. This perhaps partly reflects the effect of newer houses. Data on average age of residences (houses/apartments) are not available.

Table 2 shows positive coefficients for the proportion of households with a mortgage, at the $1 \%$ significance level. A percentage-point increase in the proportion of households with a mortgage is associated with a 0.6 percentage-point increase in the proportion of households with solar panels in column 2. Higher motivation for solar uptake might be due to greater bill stress among mortgage holders who have to make additional housing payments compared to those who own their homes outright. The effect may also reflect debt preferences or mortgage financing of solar panels. Some of the mortgage effect in column 2 may be capturing a correlated middle-income effect, but the mortgage coefficient remains significant at the $1 \%$ level in column 3 .

Table 2 shows negative and significant coefficients for log median income. This may be evidence that bill stress is a motivator, with motivation to avoid bill stress being lower at higher incomes. We analyse income in more detail in column 3 by including variables for income distribution. There are positive and significant coefficients for the lower and upper-middle income ranges of $\mathrm{A} \$ 20,800-77,999$ and $\mathrm{A} \$ 78,000-181,999$ relative to the excluded variable for the highest income band of $A \$ 182,000$ and above. This suggests that there is a strong middle-income effect on solar uptake. It is possible that highincome postcodes may face some additional barriers to solar uptake, such as having more heritage-listed buildings for which installations are not allowed. ${ }^{9}$ We also control for the proportion of households who did not report their income, but the coefficients for this variable are not significant.

The coefficients for the spatial autoregressive term are positive and significant at the $1 \%$ level in each column, potentially representing the existence of peer effects (Bollinger and Gillingham, 2012). Many of the electricity distributor coefficients are statistically significant (results available in the online code). For example, the coefficient for the

9 The middle-income effect is similar when excluding Sydney postcodes. Some Sydney suburbs have a higher share of old residences relative to some other Australian cities such as the Gold Coast and Canberra. 
distributor covering the state of South Australia is positive and significant at the $1 \%$ level, with a magnitude of 0.09 in explaining proportional uptake. This likely reflects both high electricity prices and generous feed-in tariffs for early uptake in South Australia. The SRES binary variables have similar coefficients when excluding the distribution area variables (see the online code).

We now turn to our regression discontinuity approach, with the results shown in Table 3. The approach involves comparing postcodes on either side of a subsidy-zone border, on the assumption that neighbouring postcodes are sufficiently similar to each other so as to consider the zone allocation to be like a random assignment. We also retain the same controls in case there are any other substantial differences between border postcodes.

The regression discontinuity approach in Panel A of Table 3 shows that zone 2 has an additional 8 percentage points of solar installations per household compared to zone 3 , conditioning on the controls. This is based on a sample of 107 postcodes on the zone border and is significant at the $1 \%$ level. Column 4 of Table 2 also showed a larger positive effect for zone 2 relative to zone $3 .^{10}$

Panel A of Table 3 also shows a corresponding positive effect of a higher subsidy factor at the border of zone 3 and zone 4, although it is not statistically significant, perhaps due to the small sample of 102 postcodes. The small-sample effect is also a possible explanation for the non-significance of the regression discontinuity results at the zone 1-zone 2 border. Panel B again shows positive effects of higher subsidies on log solar capacity at the zone 2 -zone 3 border and at the zone 3 -zone 4 border, but these results are also not statistically significant.

Panel C of Table 3 shows our propensity score matching results. A positive effect of being in zone 2 relative to zone 3 is detected. The average treatment effect is an additional 7 percentage points of rooftop solar uptake in zone 2 , an effect that is significant at the $1 \%$ level. The treatment effects at the other borders are again estimated rather imprecisely for these small samples. Interestingly, we consistently find the least evidence of a positive effect of the subsidy factor in zone 1, although it should be noted

10 We also produce results without controls to increase the number of degrees of freedom. The result for zone 2 relative to zone 3 is similar. See the online code. 
that only a small share of households live in this zone (less than 1\%). Table 2 also did find that there is a relatively high number of small-scale installations in zone 1 when compared to zone 4 (ceteris paribus).

Table 3. Regression discontinuity and propensity score matching results, 31 December

\begin{tabular}{|c|c|c|c|}
\hline \multicolumn{4}{|c|}{2018} \\
\hline & $\begin{array}{l}\text { Zone 1-2 border } \\
\text { (1) }\end{array}$ & $\begin{array}{l}\text { Zone 2-3 border } \\
\text { (2) }\end{array}$ & $\begin{array}{l}\text { Zone 3- } \\
\text { (3) }\end{array}$ \\
\hline \multicolumn{4}{|c|}{$\begin{array}{l}\text { Panel A: Regression discontinuity. Dependent variable: Number of households with solar PV installat } \\
\text { divided by number of households }\end{array}$} \\
\hline SRES subsidy zone 1 (factor $=1.622)$, binary & $\begin{array}{l}-0.046 \\
(0.070)\end{array}$ & & \\
\hline SRES subsidy zone 2 (factor $=1.536$ ), binary & & $\begin{array}{l}0.075^{* * *} \\
(0.016)\end{array}$ & \\
\hline SRES subsidy zone 3 (factor $=1.382$ ), binary & & & $\begin{array}{l}0.017 \\
(0.010)\end{array}$ \\
\hline Additional controls & Yes & Yes & Yes \\
\hline$R^{2}$ & 0.96 & 0.73 & 0.79 \\
\hline \multicolumn{4}{|c|}{ Panel B: Regression discontinuity. Dependent variable: Log solar capacity } \\
\hline SRES subsidy factor, $\log$ & $\begin{array}{l}-6.553 \\
(21.053)\end{array}$ & $\begin{array}{l}0.851 \\
(0.683)\end{array}$ & $\begin{array}{l}0.428 \\
(0.335)\end{array}$ \\
\hline Additional controls & Yes & Yes & Yes \\
\hline$R^{2}$ & 0.97 & 0.95 & 0.98 \\
\hline
\end{tabular}

Panel C: Propensity score matching. Dependent variable: Number of households with solar PV installations divided by number of households
Average treatment effect (from being in the
$-0.094 *$
$0.070^{* * *}$
0.012
zone with higher subsidy)
$(0.048)$
$(0.019)$
(0.016)
Observation numbers (for each Panel) 107 102

Notes. ${ }^{* * *},{ }^{* *}, *$ show statistical significance at 1,5 and 10 per cent level respectively. Standard errors are in brackets below the coefficients. Coefficients for constants are not shown. Panel A and B are ordinary least squares regressions for neighbouring postcodes at the zone boundaries with the same additional controls as Table 2. Solar installations are the stock as at December 2018.

\subsection{Estimates for recent flows of rooftop solar installations}

We now return to full-sample estimates. Table 4 shows results for recent installations of small-scale solar, with the dependent variable being the log of the capacity of installations in kilowatts for each postcode during an individual year of the period 2015-2018. The control set includes all of the explanatory variables in Table 2. This includes the log of total dwellings, since the dependent variables do not account for dwelling numbers. High $R^{2}$ values of up to 0.84 are obtained.

The primary result on the positive effect of the SRES on solar uptake is maintained in Table 4, with statistical significance at the 1\% level for installations during 2017 and at 
the $5 \%$ level for installations during 2018. The subsidy elasticity of solar capacity additions in 2018 is estimated as being 1.2, indicating that a 1\% higher subsidy factor was associated with $1.2 \%$ more small-scale solar capacity being installed in that year. Interestingly, the log SRES coefficients are also positive for 2015 and 2016 installations, but are not statistically significant. Note that overall rooftop solar installation rates were much larger in 2017 and 2018, so the significant effects for these years are of particular importance. The SRES also had significant effects prior to 2015; the online code shows that the SRES subsidy factor's effect on cumulative capacity up to 2014 was similar to the effect up to 2018 .

Table 4. Results, log solar PV capacity additions during each year.

\begin{tabular}{|c|c|c|c|c|}
\hline & \multicolumn{4}{|c|}{ Dependent variable: Log solar capacity additions during: } \\
\hline & 2015 & 2016 & 2017 & 2018 \\
\hline \multirow[t]{2}{*}{ SRES subsidy factor, $\log$} & 0.520 & 0.103 & $1.627 * * *$ & $1.150^{* *}$ \\
\hline & $(0.467)$ & $(0.606)$ & $(0.474)$ & $(0.452)$ \\
\hline Additional controls & Yes & Yes & Yes & Yes \\
\hline$R^{2}$ & 0.81 & 0.69 & 0.81 & 0.84 \\
\hline \multicolumn{5}{|c|}{$\begin{array}{l}\text { Notes. } * * *, * * * \text { show statistical significance at } 1,5 \text { and } 10 \text { per cent level respectively. } \\
\text { Standard errors are in brackets below the coefficients. There are } 2,213 \text { observations in each } \\
\text { column. The dependent variable uses the inverse hyperbolic sine transformation so that the } \\
\text { small numbers of postcodes without capacity additions in a year are retained. For example, } 35 \\
\text { f } 2,213 \text { postcodes did not have any solar installations during } 2017 \text {. The coefficient for the } 2017 \\
\text { egression is still 1.6, significant at the } 1 \% \text { level, if the inverse hyperbolic sine transformation is } \\
\text { not used (see the online code). The additional controls include all variables from Table } 2 \text {. }\end{array}$} \\
\hline
\end{tabular}

\subsection{Quantifying the impact of the Small-scale Renewable Energy Scheme (SRES)}

We now use our estimates to quantify the impact of a hypothetical increase in the perunit subsidies paid for new installations under the SRES. We use the result that a $10 \%$ higher subsidy factor on average boosts the flow of solar capacity by $12 \%$, based on the elasticity for the flow of additions in 2018 in Table 4. This is a reduced-form finding, reflecting both higher quantity demanded and higher quantity supplied in postcodes with higher SRES subsidy factors. Our use of the elasticity from the regression results is beneficial as it allows for calculation of a marginal subsidy cost per tonne of $\mathrm{CO}_{2}$ abatement rather than an average subsidy cost. Our approach avoids the need to make assumptions about how much additional capacity would be installed if higher subsidy factors were to be applied.

Our analysis focuses on costs and benefits over the course of the 13-year SRES deeming period from 2018. We calculate undiscounted costs and benefits because the 
subsidy cost is upfront, and because the exact timing of the emissions-reduction benefits within a 13-year window is relatively unimportant given that we are considering a global stock externality and that many of the damages from climate change will occur further into the future.

We first calculate the additional cost in Australian dollars resulting from a hypothetical $10 \%$ increase in the average subsidy factor. We base the calculations on the year 2018 , when 1.5 gigawatts of small-scale solar capacity additions were added under the current arrangement. There are two components to the additional subsidy cost:

(i) The additional subsidy cost flowing to installations that would have been installed anyway (the inframarginal effect)

(ii) The cost for additional installations that would have been induced by a $10 \%$ increase in the average subsidy factor (the marginal effect)

The cost for the inframarginal component (i) is $\mathrm{A} \$ 90.8$ million. It is the product of:

- The observed year-2018 capacity additions of 1.5 gigawatts.

- The average subsidy factor of 1.33 , which is an average calculated by weighting the subsidy factors by the number of postcodes in each zone. Weighting by the number of dwellings in each zone also produces an average subsidy factor of 1.33 .

- The $10 \%$ increase in the average subsidy factor.

- A certificate price of $\mathrm{A} \$ 35$ per certificate (consistent with prices in October 2018, and similar to previous periods).

- The deeming period of 13 years that applied in 2018 .

The cost for the marginal component (ii) is A $\$ 119.8$ million, calculated as the product of:

- Additional capacity of 180,000 kilowatts, based on an elasticity of 1.2 applied to the 1.5 gigawatts installed during 2018 and the hypothetical 10\% increase in the average subsidy factor.

- 1.33 multiplied by 1.1 , the average subsidy factor after the $10 \%$ increase.

- A certificate price of $A \$ 35$ per certificate.

- The deeming period of 13 years that applied in 2018 . 
We then calculate the corresponding $\mathrm{CO}_{2}$ emissions reduction for a $10 \%$ increase in the average subsidy factor. The avoided emissions are 4.1 million tonnes, calculated as the product of:

- Additional capacity installations of 180,000 kilowatts (as above).

- The 13-year deeming period, 365 days in a year, 24 hours in day, and an assumed capacity factor of 0.2 . This product converts kilowatts into kilowatt hours for the full deeming period.

- An assumed carbon intensity of displaced emissions of 0.001 tonnes of $\mathrm{CO}_{2}$ per kilowatt hour. ${ }^{11}$

We then sum the inframarginal and marginal effects to give a total additional subsidy cost of A $\$ 210.6$ million from a 10\% increase in the average subsidy factor. Dividing by the additional emissions reductions gives a subsidy cost of around A $\$ 51$ per tonne of $\mathrm{CO}_{2}$ emissions abated. This is equal to US\$36 per tonne, converted using an exchange rate of 0.7 US dollars per A\$.

Our calculation is sensitive to assumptions, and does not consider the private investment costs of panel installations or any benefits other than $\mathrm{CO}_{2}$ abatement. It does, however, provide a ballpark figure for assessing the cost-effectiveness of the SRES in achieving the aim of abating $\mathrm{CO}_{2}$ emissions. The result is substantially lower than findings for US regions. US findings include subsidy costs of approximately US\$160 per tonne of $\mathrm{CO}_{2}$ for California (Hughes and Podolefsky, 2015), US\$184 per tonne for the north-east of the US (Crago and Chernyakhovskiy, 2017), and US\$364 per tonne for Connecticut in 2014 (Gillingham and Tsvetanov, 2019).

There are several likely reasons for our lower subsidy cost finding. The per-unit subsidy in the Australian SRES has been comparatively small, at approximately US $\$ 0.50$ per watt, relative to an average of up to US\$1.72 per watt in California (Hughes and Podolefsky, 2015). Solar conditions in the north-east US are not as favourable as in Australia. Further, electricity in Australia has substantially higher carbon intensity than

11 We chose a solar capacity factor of 0.2 as it is in between the 0.18 used by Hughes and Podolefsky (2015) for California and a capacity factor of 0.25 for solar energy in Australia that includes more efficient utility-scale installations (Finkel et al., 2017). The carbon intensity assumption is based on Australian coal power plant intensities, some of which are likely to close in coming years (Finkel et al., 2017). 
the corresponding north-east US value of approximately 0.0003 tonnes of $\mathrm{CO}_{2}$ per kilowatt hour (Gillingham and Tsvetanov, 2019).

Our calculation of US $\$ 36$ of subsidy per tonne is similar to the year-2016 estimates of the social cost of $\mathrm{CO}_{2}$ of the US government (Nature, 2017), which also equalled around US\$36. Much higher estimates also exist in the literature (Hepburn, 2017). These comparisons provide a degree of justification for the SRES, given that the subsidy cost of reducing emissions using a hypothetical increase in the average SRES subsidy factor does not appear to exceed key estimates of the social cost of emitting. However, there are likely to be lower-cost approaches to reducing emissions using other energy generation technologies. For example, utility-scale solar projects are often more cost effective (Climate Change Authority, 2014). Australia's former carbon price, in place from July 2012 to June 2014, started at A \$23 (US\$16 using an exchange rate of 0.7 \$US per A\$) per tonne of $\mathrm{CO}_{2}$, meaning that it was likely incentivising more costeffective emissions reductions than the SRES.

Table 5 shows a sensitivity analysis, with a focus on assumptions regarding the lifetime of solar panels and the assumed carbon intensity of displaced electricity. For the lifetime of solar panels, we consider a period of 20 years as an alternative to the year2018 deeming period of 13 years. ${ }^{12}$ For the carbon intensity of displaced electricity, we consider the average carbon intensity of Australia's National Electricity Market (Finkel et al., 2017). This is $20 \%$ lower than our earlier assumption of 0.001 tonnes of $\mathrm{CO}_{2}$ per kilowatt hour, which was based on the carbon intensity of a representative coalfired power station. US\$36 per tonne of $\mathrm{CO}_{2}$ falls within the range of the estimates shown in Table 5.

12 The realised lifetime of rooftop solar installations will depend on factors such as prices and the pace of technological change. 
Table 5. Sensitivity analysis: Subsidy cost per tonne of $\mathrm{CO}_{2}$ (US\$) resulting from a hypothetical increase in the subsidy factors

\begin{tabular}{lcc}
\hline Carbon intensity of displaced electricity & \multicolumn{2}{c}{ Solar panel life } \\
\cline { 2 - 3 } & 13 years & 20 years \\
\hline 0.001 tonnes of $\mathrm{CO}_{2}$ per kilowatt hour & 36 & 23 \\
0.0008 tonnes of $\mathrm{CO}_{2}$ per kilowatt hour & 45 & 29 \\
\hline
\end{tabular}

Note: These estimates use the flow elasticity for 2018 from Table 4.

\section{Conclusions and policy implications}

Our results suggest that the price subsidy introduced by Australia's SRES has had a major impact on Australian small-scale uptake. Looking across postcodes, a 1\% higher subsidy factor was associated with around 1.2\% more small-scale solar PV capacity being put in during calendar year 2018. In terms of cost effectiveness, we calculate that an increase in the subsidy factors for new installations would be able to reduce $\mathrm{CO}_{2}$ emissions at a subsidy cost of around US\$36 per tonne. We also show that solar uptake is higher in postcodes with higher proportions of mortgage holders, middle-income households, and households that have recently moved.

Greater geographic targeting of subsidies to areas with more solar exposure is a possible approach for schemes of this type. Currently, the subsidy factor varies considerably less than do underlying solar conditions; some postcodes in the Australian state of Queensland receive the same subsidy as some postcodes in the state of Victoria, despite receiving much more solar exposure. There is a trade-off between efficiency and other considerations, including equity and simplicity of scheme design. Other factors, such as proximity to adequate distribution infrastructure, are also likely to be relevant for determining optimal subsidy factors for rooftop solar PV. Our findings suggest that there is a potential for greater targeting of remote and very remote areas, which tend to have lower uptake.

An additional opportunity is to take steps to better facilitate the market for solar panel leasing, including by seeking to overcome coordination problems (Bardhan et al., 2014). Rai and Sigrin (2013) conclude that leasing solar panels is an effective way to expand the residential solar PV market to consumers with tight budget constraints. In the Australian context, our findings suggest that this could refer primarily to households with annual incomes below A $\$ 20,800$. 


\section{References}

ABS, Australian Bureau of Statistics. 2018. http://www.abs.gov.au.

AEMO, Australian Energy Market Operator. 2018. Integrated system plan. July 2018.

AER, Australian Energy Regulator. 2017. State of the Energy Market. May 2017.

Ameli, N., Brandt, N., 2015. Determinants of households' investment in energy efficiency and renewables: Evidence from the OECD survey on household environmental behaviour and attitudes. Environ. Res. Lett. 10. https://doi.org/10.1088/1748-9326/10/4/044015

Australian Electoral Commission. 2016. 2016 Federal Election House of Representatives First Preferences by Candidate by Polling Place. https://results.aec.gov.au, accessed May 20, 2018.

Australian Government. 2018. Renewable Energy (Electricity) Regulations 2001. https://www.legislation.gov.au/Details/F2018d00221, https://www.legislation.gov.au/Details/C2015B00071, accessed May 19, 2018.

Australian PV Institute. 2019. PV Postcode Data. Solar Map, funded by the Australian Renewable Energy Agency, accessed from pv-map.apvi.org.au on 1 May 2019.

Australian Taxation Office. 2018. Table 28 by postcode, for the 2015-16 income year, www.ato.gov.au, accessed June 13, 2018.

Aydin, E., Eichholtz, P., Yönder, E., 2018. The economics of residential solar water heaters in emerging economies: The case of Turkey. Energy Econ. 75, 285-299. https://doi.org/10.1016/j.eneco.2018.08.001

Bardhan, A., Jaffee, D., Kroll, C., Wallace, N., 2014. Energy efficiency retrofits for U.S. housing: Removing the bottlenecks. Reg. Sci. Urban Econ. 47, 45-60. https://doi.org/10.1016/j.regsciurbeco.2013.09.001

Best, R., Burke, P.J., 2018. Adoption of solar and wind energy: The roles of carbon pricing and aggregate policy support. Energy Policy 118, 404-417.

Best, R., Burke, P.J., Nishitateno, S., in press. Understanding the determinants of rooftop solar installation: evidence from household surveys in Australia. Australian Journal of Agricultural and Resource Economics, 59, 1-18.

Bollinger, B., Gillingham, K., 2012. Peer Effects in the Diffusion of Solar Photovoltaic Panels. Mark. Sci. 31, 900-912. https://doi.org/10.1287/mksc.1120.0727

Bondio, S., Shahnazari, M., McHugh, A., 2018. The technology of the middle class: Understanding the fulfilment of adoption intentions in Queensland's rapid uptake residential solar photovoltaics market. Renew. Sustain. Energy Rev. 93, 642-651. https://doi.org/10.1016/j.rser.2018.05.035

Briguglio, M., Formosa, G., 2017. When households go solar: Determinants of uptake of a Photovoltaic Scheme and policy insights. Energy Policy 108, 154-162. https://doi.org/10.1016/j.enpol.2017.05.039

Bruegge, C., Carrión-Flores, C., Pope, J.C., 2016. Does the housing market value energy efficient homes? Evidence from the energy star program. Reg. Sci. Urban Econ. 57, 63-76. https://doi.org/10.1016/j.regsciurbeco.2015.12.001 
Bureau of Meterology. 2018. Solar exposure for Australia. http://www.bom.gov.au/jsp/awap/solar/index.jsp, accessed July 19, 2018.

Chapman, A.J., McLellan, B., Tezuka, T., 2016. Residential solar PV policy: An analysis of impacts, successes and failures in the Australian case. Renewable Energy 86, 1265-1279.

Clean Enegy Regulator. 2019. Postcode data for small-scale installations, Australian Government. http://www.cleanenergyregulator.gov.au/RET/Forms-andresources/Postcode-data-for-small-scale-installations accessed April 16, 2019.

Climate Change Authority. 2014. Renewable Energy Target Review Report, December 2014, Australian Government.

Country Solar NT. 2018. Residential pricing schedule. https://www.countrysolarnt.com.au/stage/residential/pricing-schedule/, accessed September 30, 2018.

Crago, C.L., Chernyakhovskiy, I., 2017. Are policy incentives for solar power effective? Evidence from residential installations in the Northeast. J. Environ. Econ. Manage. 81, 132-151. https://doi.org/10.1016/j.jeem.2016.09.008

De Groote, O., Pepermans, G., Verboven, F., 2016. Heterogeneity in the adoption of photovoltaic systems in Flanders. Energy Econ. 59, 45-57. https://doi.org/10.1016/j.eneco.2016.07.008

Department of Industry, Innovation and Science. 2015. Air Con Climate Data July 7 2015. https://data.gov.au/dataset/air-con-climate-data-july-7-2015, accessed September 30, 2018.

Dharshing, S., 2017. Household dynamics of technology adoption : A spatial econometric analysis of residential solar photovoltaic ( PV ) systems in Germany. Energy Research \& Social Science 23, 113-124. https://doi.org/10.1016/j.erss.2016.10.012

Finkel, A., Moses, K., Munro, C., Effeney, T., O’Kane, M. 2017. Independent Review into the Future Security of the National Electricity Market. Blueprint for the Future. Commonwealth of Australia. June 2017.

Gillingham, K., Tsvetanov, T. 2019. Hurdle and steps: Estimating demand for solar photovoltaics. Quant. Econ. 10, 275-310.

Hepburn, C., 2017. Climate change economics: Make carbon pricing a priority. Nat. Clim. Chang. 7, 389-390. https://doi.org/10.1038/nclimate3302

Hughes, J.E., Podolefsky, M., 2015. Getting Green with Solar Subsidies: Evidence from the California Solar Initiative. Journal of the Association of Environmental and Resource Economists 2, 235-275.

Kahn, M.E., Kok, N. 2014. The capitalization of green labels in the California housing market. Reg. Sci. Urban Econ. 47, 25-34.

Karakaya, E., Sriwannawit, P., 2015. Barriers to the adoption of photovoltaic systems: The state of the art. Renew. Sustain. Energy Rev. 49, 60-66. https://doi.org/10.1016/j.rser.2015.04.058 
Kwan, C.L., 2012. Influence of local environmental, social, economic and political variables on the spatial distribution of residential solar PV arrays across the United States. Energy Policy 47, 332-344. https://doi.org/10.1016/j.enpol.2012.04.074

Ma, C., Polyakov, M., Pandit, R., 2015. Capitalisation of residential solar photovoltaic systems in Western Australia. Australian Journal of Agricultural and Resource Economics 60, 366-385.

Macintosh, A., Wilkinson, D., 2011. Searching for public benefits in solar subsidies: A case study on the Australian government's residenital photovoltaic rebate program. Energy Policy 39, 3199-3209.

Mountain, B., Szuster, P., 2015. Solar, solar everywhere: Opportunities and challenges for Australia's rooftop PV systems. IEEE power and energy magazine, july/august 2015.

Moran, A.P.A.P., 1950. Notes on Continuous Stochastic Phenomena. Biometrika. 371, $17-23$.

Nature. 2017. Pricing the planet. Nature, 541, 260.

OECD, Organisation for Economic Cooperation and Development. 2016. Renewable Energy Medium-Term Market Report 2016. Market Analysis and Forecasts to 2021. OECD/IEA, France.

Parliament of Australia, 2010. Renewable Energy Target (RET).

https://www.aph.gov.au/About_Parliament/Parliamentary_Departments/Parliament ary_Library/Browse_by_Topic/ClimateChangeold/governance/domestic/national/ mandatory, accessed 15 April, 2019.

Rai, V., Sigrin, B., 2013. Diffusion of environmentally-friendly energy technologies: Buy versus lease differences in residential PV markets. Environ. Res. Lett. 8. https://doi.org/10.1088/1748-9326/8/1/014022

Raschky, P.A., Rosetti, J., 2014. Valuation of Australia's Green Infrastructure: Hedonic Pricing Model Using the Enhanced Vegetation Index, Department of Economics, Monash University, mimeo, original data: AusCover TERN: Phenology - MODIS, derived from MOD13C1 EVI, Australia coverage, http://data.auscover.org.au/xwiki/bin/view/Product+pages/Phenology+MOD13C2+ UTS

Roberts, M.B., Bruce, A., MacGill, I., 2019. Opportunities and barriers for photovoltaics on multi-unit residential buildings: reviewing the Australian experience. Renewable and Sustainable Energy Reviews 104, 95-110.

SEIA. 2018. Solar Industry Research Data. Solar Energy Industries Association, Washington DC. https://www.seia.org/solar-industry-research-data, accessed October 2, 2018.

Solar Choice. 2018. Residential solar PV price index. https://www.solarchoice.net.au.

Sommerfeld, J., Buys, L., Mengersen, K., Vine, D., 2017. Influence of demographic variables on uptake of domestic solar photovoltaic technology. Renew. Sustain. Energy Rev. 67, 315-323. https://doi.org/10.1016/j.rser.2016.09.009

Sunny Solar. 2018. Latest prices. http://www.sunnysolar.com.au/system-prices/, 
accessed September 30, 2018.

\section{Appendix}

Table A.1 Description of variables

\begin{tabular}{|c|c|c|}
\hline Variable & Data source & Description \\
\hline $\begin{array}{l}\text { Proportion of households } \\
\text { with solar installations }\end{array}$ & $\begin{array}{l}\text { Clean Energy } \\
\text { Regulator (2019), } \\
\text { ABS (2018) }\end{array}$ & $\begin{array}{l}\text { Number of solar PV installations of less than } 100 \\
\text { kilowatts, divided by the number of households. }\end{array}$ \\
\hline Kilowatts of PV installed & $\begin{array}{l}\text { Clean Energy } \\
\text { Regulator (2019) }\end{array}$ & $\begin{array}{l}\text { Total capacity of solar PV installations of less than } \\
100 \text { kilowatts. Measured in kilowatts. }\end{array}$ \\
\hline SRES subsidy factor & $\begin{array}{l}\text { Australian } \\
\text { Government } \\
(2018)\end{array}$ & $\begin{array}{l}\text { The Small-scale Renewable Energy Scheme } \\
\text { (SRES) subsidy factor takes one of four values: } \\
1.185,1.382,1.536 \text {, or } 1.622 \text {. Postcodes with } \\
\text { greater solar exposure benefit from higher subsidy } \\
\text { factors. In a separate specification, we also use } \\
\text { binary variables for subsidy zones. }\end{array}$ \\
\hline $\begin{array}{l}\text { Electricity distribution } \\
\text { network area }\end{array}$ & $\begin{array}{l}\text { Electricity } \\
\text { distributors } \\
\text { (websites and } \\
\text { email } \\
\text { correspondence) }\end{array}$ & $\begin{array}{l}16 \text { binary variables for electricity distribution } \\
\text { network area. Four Australian states/territories have } \\
\text { one electricity distributor, Victoria has five, New } \\
\text { South Wales has three, Western Australia has two, } \\
\text { and Queensland has two (and a small number of } \\
\text { Queensland postcodes are covered by a New South } \\
\text { Wales distributor). Some postcodes have two } \\
\text { distributors. }\end{array}$ \\
\hline Climate zone & $\begin{array}{l}\text { Department of } \\
\text { Industry (2015) }\end{array}$ & $\begin{array}{l}\text { Binary variables for } 69 \text { climate zones across } \\
\text { Australia. The Nationwide House Energy Rating } \\
\text { Scheme, administered by the Australian } \\
\text { Government, categorizes postcodes into } 69 \text { regions } \\
\text { based on climatic conditions. }\end{array}$ \\
\hline Remoteness code & ABS (2018) & $\begin{array}{l}\text { Binary variables for } 5 \text { remoteness codes based on } \\
\text { the ABS Remoteness Structure (ABS, 2018). The } \\
\text { five categories are major cities ( } 41 \% \text { of postcodes), } \\
\text { inner regional }(26 \%) \text {, outer regional }(25 \%) \text {, remote } \\
(5 \%) \text {, and very remote }(3 \%) \text {. If a postcode has more } \\
\text { than one remoteness code, categories are based on } \\
\text { the main classification. }\end{array}$ \\
\hline Number of households & ABS (2018) & Total dwellings; 2016 ABS Census. \\
\hline Area, square kilometres & ABS (2018) & Area in square kilometres. \\
\hline $\begin{array}{l}\text { Enhanced vegetation } \\
\text { index }\end{array}$ & $\begin{array}{l}\text { Raschky and } \\
\text { Rosetti (2014) }\end{array}$ & $\begin{array}{l}\text { Enhanced vegetation index - Australia 2012: mean } \\
\text { value of green infrastructure (Raschky and Rosetti, } \\
\text { 2014). }\end{array}$ \\
\hline
\end{tabular}




\begin{tabular}{|c|c|c|}
\hline Solar exposure & $\begin{array}{l}\text { Bureau of } \\
\text { Meteorology } \\
(2018)\end{array}$ & $\begin{array}{l}\text { Average of } 12 \text { monthly values (July } 2017 \text { - June } \\
2018 \text { ) of total solar energy for a day falling on a } \\
\text { horizontal surface, measured from midnight to } \\
\text { midnight. The unit is megajoules per metre squared. } \\
\text { Postcode values are averages of component areas of } \\
500 \text { by } 500 \text { metres. }\end{array}$ \\
\hline $\begin{array}{l}\text { Rented households } \\
\% / 100\end{array}$ & ABS (2018) & $\begin{array}{l}\text { Number of rented dwellings divided by the total } \\
\text { number of households. }\end{array}$ \\
\hline $\begin{array}{l}\text { Unit (flats/apartments) } \\
\% / 100\end{array}$ & ABS (2018) & $\begin{array}{l}\text { Number of flats or apartments (in any building), } \\
\text { divided by the total number of households. }\end{array}$ \\
\hline $\begin{array}{l}\text { One bedroom or less, } \\
\% / 100\end{array}$ & ABS (2018) & $\begin{array}{l}\text { Number of households with zero or one bedroom } \\
\text { (private dwellings) divided by the total number of } \\
\text { households. }\end{array}$ \\
\hline $\begin{array}{l}\text { One-year mobility } \\
\text { indicator, } \% / 100\end{array}$ & ABS (2018) & $\begin{array}{l}\text { Proportion of households where all residents in the } \\
\text { household aged one year and over had a different } \\
\text { address one year ago. }\end{array}$ \\
\hline $\begin{array}{l}\text { Environmental vote } \\
\% / 100\end{array}$ & $\begin{array}{l}\text { Australian } \\
\text { Electoral } \\
\text { Commission } \\
(2016)\end{array}$ & $\begin{array}{l}\text { Environmental votes divided by total votes in each } \\
\text { postcode in the } 2016 \text { federal election. } \\
\text { Environmental votes include: "The Greens", "The } \\
\text { Greens (WA)", "Sustainable Australia", and } \\
\text { "Renewable Energy Party". }\end{array}$ \\
\hline Proportion in age groups & ABS (2018) & $\begin{array}{l}\text { Proportion of postcode residents aged from } 40-60 \text {, } \\
\text { and over } 60 \text { years. }\end{array}$ \\
\hline Mortgage $\% / 100$ & ABS (2018) & $\begin{array}{l}\text { Number of dwellings owned with a mortgage } \\
\text { divided by the total number of households. }\end{array}$ \\
\hline $\begin{array}{l}\text { Number of employing } \\
\text { businesses divided by } \\
\text { population }\end{array}$ & ABS (2018) & $\begin{array}{l}\text { Total number of businesses minus the number of } \\
\text { businesses that do not employ anybody in the local } \\
\text { labour market (Statistical Area Level } 4 \text { (SA4)), } \\
\text { divided by postcode population. SA4 regions are } \\
\text { larger areas than postcodes, taking into account that } \\
\text { people often live in one postcode and interact with } \\
\text { businesses in nearby postcodes. The number of } \\
\text { businesses in the SA4 region is assigned to } \\
\text { postcodes using ABS (2018) correspondence tables. } \\
\text { On average, there are } 30 \text { postcodes for every SA44 } \\
\text { region. There are immaterial effects on the results if } \\
\text { the denominator for this variable is changed to SA } 4 \\
\text { population or if this variable is excluded entirely } \\
\text { (see the online code). }\end{array}$ \\
\hline $\begin{array}{l}\text { Median superannuation } \\
\text { balance }\end{array}$ & $\begin{array}{l}\text { Australian } \\
\text { Taxation Office } \\
(2018)\end{array}$ & $\begin{array}{l}\text { Median individual superannuation balance from } \\
\text { ATO Table } 28 \text { for the } 2015 \text { - } 16 \text { income year. This is } \\
\text { the median value for all individuals in a postcode } \\
\text { that report a taxable income or loss. }\end{array}$ \\
\hline $\begin{array}{l}\text { Median individual } \\
\text { income }\end{array}$ & $\begin{array}{l}\text { Australian } \\
\text { Taxation Office } \\
(2018)\end{array}$ & $\begin{array}{l}\text { Median taxable income from ATO Table } 28 \text { for the } \\
2015-16 \text { income year. }\end{array}$ \\
\hline
\end{tabular}




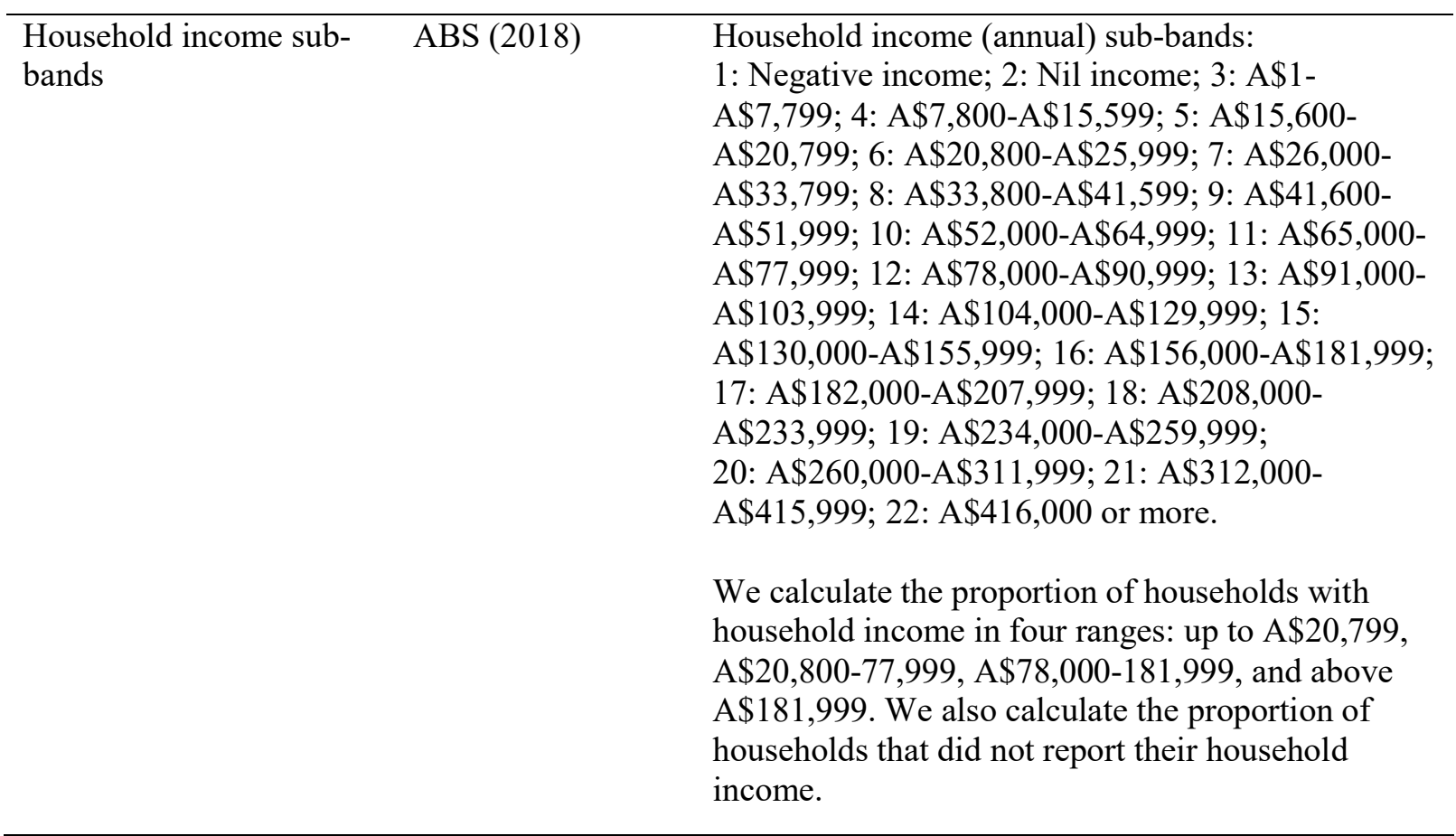

